\title{
Peran Gubernur Jambi Untuk Mengontrol Kebijakan Pemerintah Daerah dalam Menanggulangi Covid 19
}

\author{
Muhammad Jaelani ${ }^{1}$ \\ Fakultas Hukum Universitas Batanghari \\ Correspondence email : muhamadjaelani181967@gmail.com
}

\begin{abstract}
Abstrak. Dalam menjalankan tugas selaku Gubernur yang mana merupakan perpanjang tanganan pemerintah pusat di setiap provinsi maka Gubernur Jambi harus melakukan pengontrolan terkait dengan kebijakan yang telah diberlakukan oleh pemerintah daerah pada tingkat kota maupun kabupaten dalam menanggulangi covid-19. Namun, pada kenyataannya sampai sekarang ini sistem pemerintahan pada pemerintah daerah masih menjalankan pemerintahannya sendiri sendiri sehingga tidak melakukan koordinasi kepada Gubernur selaku pimpinan di provinsi daerahnya. Kondisi yang demikian ini tentunya menjadi persoalan di dalam menjalankan sistem pemerintahan sehingga perlu dikaji lebih mendalam terkait dengan peran Gubernur Jambi. Adapun pokok pembahasan yang dikaji dalam penelitian ini terkait dengan peran Gubernur Jambi di dalam mengontrol kebijakan pemerintah daerah Sehingga dalam hal ini metode penelitian yang digunakan dengan pendekatan perundang-undangan dan analisis. Bahan penelitian yang digunakan adalah bahan hukum primer, sekunder dan tersier dan teknik pengumpulan data yaitu studi pustaka serta teknik analisis nya itu kualitatif. Adapun hasil dari pembahasannya yaitu sampai sekarang ini peran Gubernur Jambi belum terlaksana dalam mengontrol kebijakan pemerintah daerah karena pemerintah daerah di dalam menjalankan pemerintahannya masih sendiri sendiri sehingga kurang bersinergi di dalam menjalankan sistem pemerintahan guna untuk menanggulangi terjadinya penyebaran covid-19.
\end{abstract}

Kata Kunci : Peran, Gubernur, Mengontrol, Kebijakan, Pemda

Abstract. In carrying out his duties as Governor, which is an extension of the central government in each province, the Jambi Governor must control the policies that have been imposed by the regional government at the city and district levels in tackling COVID-19. However, in reality until now the system of government in the regional government is still running its own government so it does not coordinate with the Governor as the leader in his regional province. This condition is certainly a problem in running the government system so that it needs to be studied more deeply related to the role of the Governor of Jambi. The subject matter studied in this study is related to the role of the Governor of Jambi in controlling local government policies. So in this case the research method used is a legislative and analytical approach. The research materials used are primary, secondary and tertiary legal materials and data collection techniques, namely literature studies and qualitative analysis techniques. The results of the discussion are that until now the role of the Governor of Jambi has not been carried out in controlling local government policies because the regional government in running its own government is still alone so that it lacks synergy in running the government system in order to cope with the spread of covid-19.

Keywords: Role, Governor, Controlling, Policy, Local Government

\section{PENDAHULUAN}

Di dalam suatu negara tentu ada berbagai macam permasalahan yang dihadapi oleh negara untuk melindungi masyarakatnya dari permasalahan yang mengancam negara tersebut. Biasanya yang masalah yang seringkali dihadapi dalam suatu negara terkait dengan perebutan kekuasaan maupun perbuatan batas wilayah. Namun hal tersebut untuk sekarang ini bukan menjadi pokok pembahasan dalam penelitian ini karena pada saat ini yang harus serius dihadapi oleh setiap negara termasuk juga Indonesia yaitu adanya corona virus disease atau biasanya disingkat dengan sebutan covid-19.

Corona virus disease (covid-19) ini berawal pada akhir tahun 2019 dan berlanjut penyebarannya pada seluruh negara di dunia tanpa terkecuali Indonesia juga. Covid-19 ini menyebar ke setiap negara dengan cara penularan melalui transmisi lokal antar penduduk sehingga pada waktu itu di setiap negara melakukan berbagai upaya untuk melindungi masyarakat yang ada di setiap negara tersebut supaya tidak terserang oleh virus covid-19 ini. Di berbagai negara telah melakukan upaya lockdown guna untuk mencegah agar masyarakatnya tidak banyak yang terserang virus covid-19 dan juga guna meminimalisir peredaran virus covid-19.

Dengan penyebaran virus covid-19 yang cepat sehingga negara Indonesia mempunyai angka positif terserang covid-19 menjadi tinggi dibandingkan dengan negara-negara lain. Melihat kondisi demikian maka virus corona virus disease ini selain mengakibatkan pada kesehatan di setiap negara, juga menimbulkan dampak di sisi ekonomi yaitu melemahkan perekonomian di suatu negara, termasuk juga dalam hal ini negara Indonesia. Selain itu, covid-19 ini

${ }^{1}$ Dosen Fakultas Hukum Universitas Batanghari 
juga mengharuskan kepada pemerintah Indonesia untuk mengambil berbagai macam kebijakan dan peraturan supaya kasus covid-19 tidak semakin meningkat di Indonesia.

Untuk itu, Presiden Joko Widodo mengadakan konferensi pers guna untuk menghubungkan kepada masyarakat Indonesia terkait dengan kebijakan yang akan digunakan bangsa Indonesia dalam menghadapi penyebaran virus corona virus disease ini. Di dalam konferensi pers tersebut, Presiden Joko Widodo mengeluarkan sebuah kebijakan yaitu kebijakan Pembatasan Sosial Berskala Besar (PSBB). PSBB ini merupakan suatu langkah yang harus dijalankan kepada negara Indonesia karena mengingat negara Indonesia dalam keadaan darurat kesehatan. Hal ini dikatakan demikian karena telah banyak masyarakat Indonesia yang menjadi korban dari adanya covid-19 ini bahkan masyarakat Indonesia banyak juga yang meninggal dunia.

Mengingat bahayanya covid-19 ini maka diberlakukan PSBB guna memberikan perlindungan kepada masyarakat Indonesia dari adanya penularan covid-19. Pernyataan ini juga telah diamanatkan dalam dasar hukum Indonesia yaitu Undang-Undang Dasar Tahun 1945 yang mana menentukan bahwa pemerintah Indonesia untuk memberikan perlindungan terhadap masyarakat atau warga negaranya dari berbagai ancaman yang mengancam warga negaranya termasuk juga adanya covid-19. Oleh karena itu, Presiden Republik Indonesia mengeluarkan suatu keputusan yaitu Keputusan Presiden Nomor 11 Tahun 2020 tentang Penetapan Kedaruratan Kesehatan Masyarakat covid-19. Dalam Keputusan Presiden tersebut dinyatakan bahwa covid-19 ini sudah termasuk darurat pada kesehatan masyarakat sehingga diperlukan upaya penanggulangan di setiap provinsi termasuk juga provinsi Jambi.

Selain itu juga, PSBB ini didasari adanya Undang-Undang Nomor 6 Tahun 2018 tentang Karantina Kesehatan. Digunakan aturan hukum ini karena berhubungan dengan PSBB sebab PSBB merupakan peristilahan yang digunakan dalam mendefinisikan terkait dengan membatasi kegiatan yang dilakukan oleh masyarakat Indonesia di dalam suatu wilayah, dimana suatu wilayah tersebut diduga telah terserang oleh covid-19 sehingga dengan adanya pembatasan ini maka dapat mencegah terjadinya penyebaran covid-19 di luar wilayah. Dilakukan pembatasan dalam hal ini karena PSBB merupakan langkah yang harus dilaksanakan oleh pemerintah guna untuk memberikan perlindungan terkait dengan kesehatan masyarakat Indonesia dari covid-19 sehingga dengan terbentuknya PSBB ini, selain mengatasi sekaligus juga meminimalisir tingginya tingkat covid-19.

Walaupun PSBB merupakan tugas yang dikerjakan oleh pemerintah, akan tetapi pemerintah baik yang ada di pusat maupun di daerah harus menerima persetujuan yang diberikan oleh Menteri Kesehatan melalui Keputusan Menteri. Hal demikian diatur dalam Peraturan Pemerintah Nomor 21 Tahun 2020 Tentang Pembatasan Sosial Berskala Besar dalam Rangka Percepatan Penanganan corona virus disease 2019 (Covid-19). Dalam hal persetujuan terkait dengan pembatasan ini Menteri Kesehatan terlebih dahulu melihat jumlah kasus yang terinfeksi covid-19 dan jumlah orang yang mati serta ada bukti transmisi lokal di daerah tersebut. Jika telah disetujui oleh Menteri Kesehatan maka pemerintah pusat maupun pemerintah daerah harus menjalankan PSBB pada kegiatan masyarakat seperti sekolah dan tempat kerja diliburkan sementara waktu, memerintahkan kepada pihak sekolah untuk melakukan pembelajaran secara online, melakukan pembatasan dalam kegiatan keagamaan dan menutup sementara tempattempat umum.

Selain kebijakan Pembatasan Sosial Berskala Besar (PSBB) yang telah diberlakukan oleh pemerintah Pusat, pemerintah Provinsi Jambi juga memberlakukan kebijakan Pemberlakuan Pembatasan Kegiatan Masyarakat (PPKM) sesuai dengan Instruksi Menteri Dalam Negeri Nomor 31 Tahun 2021 Tentang Pemberlakuan Pembatasan Kegiatan Masyarakat Level 4 Corona Virus Disease 2019 Di Wilayah Sumatera, Kalimantan, Sulawesi, Nusa Tenggara Dan Papua. Dalam Instruksi Menteri Dalam Negeri tersebut mengatur beberapa urusan yang harus dilaksanakan masyarakat kota maupun kabupaten di provinsi Jambi.

Adapun kegiatan yang diatur di dalam Instruksi Menteri Dalam Negeri Nomor 31 Tahun 2021 Tentang Pemberlakuan Pembatasan Kegiatan Masyarakat Level 4 Corona Virus Disease 2019 Di Wilayah Sumatera, Kalimantan, Sulawesi, Nusa Tenggara Dan Papua yaitu proses belajar mengajar dan perkuliahan baik pada tingkat sekolah Perguruan Tinggi dan tempat pendidikan atau pelatihan dilaksanakan secara daring (online) sehingga siswa dan mahasiswa belajar di rumah. Hal ini harus dilakukan oleh masyarakat kota maupun kabupaten yang ada di provinsi Jambi guna untuk menghindari terjadinya kerukunan.

Pengaturan terkait dengan belajar mengajar yang dilakukan secara online, di dalam Instruksi Menteri Dalam Negeri Nomor 31 Tahun 2021 Tentang Pemberlakuan Pembatasan Kegiatan Masyarakat Level 4 Corona Virus Disease 2019 Di Wilayah Sumatera, Kalimantan, Sulawesi, Nusa Tenggara Dan Papua juga mengatur terkait dengan pelaksanaan pada kegiatan sektor non esensial dilakukan $100 \%$ work from home (WFH), sedangkan pada kegiatan sektor esensial dapat beroperasi sesuai dengan ketentuan yaitu pada kegiatan keuangan dan perbankan termasuk juga asonansi dapat melakukan kegiatan perkantoran dengan kapasitas setiap atau karyawannya yang bertugas pada bidang pelayanan kepada masyarakat maksimal $50 \%$, sedangkan staf dan karyawan yang bertugas dalam pelayanan administrasi perkantoran dibatasi maksimal $25 \%$.

Kemudian pada kegiatan pasar modal kapasitas staf yang melakukan pelayanan dengan pelanggan dan berjalannya operasional pasar modal maksimal 50\%. Selanjutnya pada industri yang berorientasi pada ekspor dan 
penunjang ekspor dapat melakukan kegiatan industrinya dengan memperlakukan shift maksimal 50\% dari total pekerja dalam satu shift serta $10 \%$ bagi yang bertugas melakukan pelayanan administrasi perkantoran dengan menerapkan jadwal masuk dan pulang serta bagi karyawan yang makan di kantor tidak harus bersamaan. Selain itu juga, pada sektor pemerintahan yang mana bertugas memberikan pelayanan publik diberlakukan $25 \%$ terhadap staf Work From Office (WFO) dengan tetap menggunakan protokol kesehatan.

Selain pemberlakukan di atas masih banyak lagi pengaturan yang diatur dalam Instruksi Menteri Dalam Negeri Nomor 31 Tahun 2021 Tentang Pemberlakuan Pembatasan Kegiatan Masyarakat Level 4 Corona Virus Disease 2019 Di Wilayah Sumatera, Kalimantan, Sulawesi, Nusa Tenggara Dan Papua sehingga Pemberlakuan Pembatasan Kegiatan Masyarakat (PPKM) memang harus diterapkan di tingkat kabupaten maupun kota yang ada di provinsi Jambi. Adapun wilayah yang termasuk dalam Pemberlakuan Pembatasan Kegiatan Masyarakat (PPKM) Level 4 di Provinsi Jambi yaitu Kabupaten Batanghari, Kabupaten Merangin, dan Kota Jambi. Dengan demikian, wilayahwilayah yang telah disebut itu harus menerapkan Pemberlakuan Pembatasan Kegiatan Masyarakat (PPKM). Dalam hal penetapan level Pemberlakuan Pembatasan Kegiatan Masyarakat (PPKM) ini disesuaikan dengan indikatorindikator yang sudah ditetapkan oleh Menteri Kesehatan. ${ }^{2}$

Dengan telah dikeluarkannya Instruksi Menteri Dalam Negeri tersebut maka sudah seharusnya Pemerintah Provinsi harus bekerjasama dengan Pemerintah Kabupaten/Kota Jambi guna untuk menjalankan Pemberlakuan Pembatasan Kegiatan Masyarakat (PPKM) di Provinsi Jambi. Akan tetapi, pada kenyataannya dalam menjalankan Pemberlakuan Pembatasan Kegiatan Masyarakat (PPKM) tersebut antara Pemerintah Provinsi Jambi dengan Pemerintah Kota maupun Kabupaten yang ada di Provinsi Jambi melakukan kebijakan masing-masing sehingga sulit untuk Pemerintah provinsi Jambi di dalam melakukan pengawasan atau pengontrolan kebijakan Pemerintah Daerah dalam hal penanggulangan covid-19 di Provinsi Jambi.

Melihat kondisi yang demikian tentunya penulis melakukan pembatasan guna untuk membatasi pokok pembahasan dalam penelitian ini. Adapun permasalahan yang dibahas dalam penelitian ini yaitu terkait dengan bagaimana peran gubernur Jambi untuk mengontrol kebijakan pemerintah daerah dalam menanggulangi covid-19. Untuk itu, tujuan di dalam penelitian ini adalah untuk mengetahui dan menambah wawasan baik kepada masyarakat Provinsi Jambi maupun pemerintahan daerah terkait peran gubernur Jambi untuk mengontrol kebijakan pemerintah daerah dalam menanggulangi covid-19.

\section{METODE}

Metode penelitian digunakan untuk mempermudah peneliti dalam melakukan langkah-langkah penelitian sehingga mempermudah peneliti dalam menjelaskan terkait dengan kasus atau peristiwa yang sedang diteliti. Adapun metode penelitiannya sebagai berikut :

1. Pendekatan

Penelitian tentang peran gubernur Jambi untuk mengontrol kebijakan pemerintah daerah dalam menanggulangi covid-19 menggunakan pendekatan perundang-undangan dan pendekatan analisis. Pendekatan perundang-undangan yaitu suatu penelitian hukum dengan mengutamakan peraturan perundang-undangan sebagai pedoman dalam menganalisis isu hukum yang sedang terjadi. ${ }^{3}$ Adapun peraturan perundang-undangan yang digunakan dalam penelitian ini yaitu Undang-Undang Dasar Negara Republik Indonesia Tahun 1945, UndangUndang Nomor 6 Tahun 2018 tentang Karantina Kesehatan, Undang-Undang Nomor 23 Tahun 2014 Tentang Pemerintahan Daerah, Keputusan Presiden Nomor 11 Tahun 2020 tentang Penetapan Kedaruratan Kesehatan Masyarakat corona virus disease 2019 (covid-19), Peraturan Pemerintah Nomor 21 Tahun 2020 Tentang Pembatasan Sosial Berskala Besar dalam Rangka Percepatan Penanganan corona virus disease 2019 (Covid-19), Peraturan Pemerintah Nomor 25 Tahun 2000 Tentang Kewenangan Pemerintah Dan Kewenangan Propinsi Sebagai Daerah Otonom, Instruksi Menteri Dalam Negeri Nomor 31 Tahun 2021 Tentang Pemberlakuan Pembatasan Kegiatan Masyarakat Level 4 Corona Virus Disease 2019 Di Wilayah Sumatera, Kalimantan, Sulawesi, Nusa Tenggara, Dan Papua, Instruksi Walikota Jambi Nomor : 18/INS/VIII/HKU/2021 Tentang Pemberlakuan Pembatasan Kegiatan Masyarakat Level 4 Corona Virus Disease Di Wilayah Kota Jambi, Peraturan Bupati Batanghari Nomor 26 Tahun 2021 Tentang Perubahan Atas Peraturan Bupati Batanghari Nomor 65 Tahun 2020 Tentang Penerapan Disiplin Dan Penegakan Hukum Protokol Kesehatan Sebagai Upaya Pencegahan Dan Pengendalian Corona Virus Disease 2019.

Kemudian pendekatan analisis yaitu suatu pendekatan dengan menganalisa berbagai macam bahan hukum seperti perundang-undangan untuk mengetahui makna yang terdapat di dalam bahan hukum tersebut sehingga mengetahui terkait dengan penerapan hukum itu pada praktiknya. ${ }^{4}$ Dengan menggunakan pendekatan analisis maka

\footnotetext{
${ }^{2}$ https://regional.kontan.co.id/news/berlaku-hingga-23-agustus-ini-daftar-wilayah-ppkm-level-4-di-luar-pulau-jawa-bali, Diunduh tanggal 9 Agustus 2021.

3 Peter Mahmud Marzuki, Penelitian Hukum, (Jakarta : Kencana Prenada Media Group, 2011), hal 24.

${ }^{4}$ Johnny Ibrahim, Teori dan Metodologi Penelitian Hukum Normatif, (Malang : Bayumedia Publishing, 2012 ), hal 310.
} 
peneliti harus menjelaskan terkait dengan apa saja unsur yang tercantum dalam aturan hukum tersebut kemudian dihubungkan dengan peristiwa yang telah terjadi sehingga mempermudah dalam menjelaskan dan memahami permasalahan tentang peran Gubernur Jambi untuk mengontrol kebijakan pemerintah daerah dalam menanggulangi covid-19.

2. Rancangan Kegiatan

Di dalam setiap melakukan penelitian tentu ada rencana kegiatan sehingga mempermudah peneliti untuk melakukan penelitian. Adapun rencana kegiatan yang dilaksanakan pada penelitian tentang peran Gubernur Jambi untuk mengontrol kebijakan pemerintah daerah dalam menanggulangi covid-19 yaitu selama 1 (satu) bulan.

3. Ruang Lingkup Atau Objek

Di dalam penelitian ini, ruang lingkupnya mengkaji terkait dengan peran Gubernur Jambi dalam mengontrol kebijakan pemerintah daerah untuk melakukan penanggulangan terjadinya covid-19 sehingga objek yang digunakan di dalam penelitian tentang peran Gubernur Jambi untuk mengontrol kebijakan pemerintah daerah dalam menanggulangi covid-19 yaitu peran Gubernur Jambi dalam mengontrol kebijakan pemerintah daerahnya.

4. Bahan Dan Alat Utama

Bahan hukum primer yaitu bahan hukum resmi yang bersifat publik dan dikeluarkan oleh badan legislatif seperti peraturan perundang-undangan. ${ }^{5}$ Adapun bahan hukum primer dalam penelitian ini sebagai berikut :

a. Undang-Undang Dasar Negara Republik Indonesia Tahun 1945.

b. Undang-Undang Nomor 6 Tahun 2018 tentang Karantina Kesehatan.

c. Undang-Undang Nomor 23 Tahun 2014 Tentang Pemerintahan Daerah.

d. Keputusan Presiden Nomor 11 Tahun 2020 tentang Penetapan Kedaruratan Kesehatan Masyarakat corona virus disease 2019 (covid-19).

e. Peraturan Pemerintah Nomor 21 Tahun 2020 Tentang Pembatasan Sosial Berskala Besar dalam Rangka Percepatan Penanganan corona virus disease 2019 (Covid-19).

f. Peraturan Pemerintah Nomor 25 Tahun 2000 Tentang Kewenangan Pemerintah Dan Kewenangan Propinsi Sebagai Daerah Otonom.

g. Instruksi Menteri Dalam Negeri Nomor 31 Tahun 2021 Tentang Pemberlakuan Pembatasan Kegiatan Masyarakat Level 4 Corona Virus Disease 2019 Di Wilayah Sumatera, Kalimantan, Sulawesi, Nusa Tenggara, Dan Papua.

h. Instruksi Walikota Jambi Nomor : 18/INS/VIII/HKU/2021 Tentang Pemberlakuan Pembatasan Kegiatan Masyarakat Level 4 Corona Virus Disease Di Wilayah Kota Jambi.

i. Peraturan Bupati Batanghari Nomor 26 Tahun 2021 Tentang Perubahan Atas Peraturan Bupati Batanghari Nomor 65 Tahun 2020 Tentang Penerapan Disiplin Dan Penegakan Hukum Protokol Kesehatan Sebagai Upaya Pencegahan Dan Pengendalian Corona Virus Disease 2019.

Bahan hukum sekunder merupakan bahan hukum yang telah dipublikasikan Namun bukan dalam bentuk dokumen resmi seperti perundang-undangan. Adapun bahan hukum sekunder yang dimaksud sebagai berikut : ${ }^{6}$

a. Buku-buku literatur.

b. Jurnal hukum.

c. Hasil penelitian.

d. Komentar-komentar atas putusan pengadilan.

Untuk itu, bahan hukum sekunder dalam penelitian ini yaitu Buku-buku literatur dan jurnal hukum. Sedangkan bahan hukum tersier yaitu bahan hukum yang digunakan sebagai pelengkap dan menjelaskan terhadap bahan hukum primer dan bahan hukum sekunder. Adapun bahan hukum tersier seperti contoh kamus besar bahasa indonesia (KBBI), ensiklopedia, indeks kumulatif dan seterusnya. ${ }^{7}$ Penelitian ini menggunakan bahan hukum tersier berupa website internet yang berkaitan dengan permasalahan tentang peran Gubernur Jambi untuk mengontrol kebijakan pemerintah daerah dalam menanggulangi covid-19.

5. Teknik Pengumpulan Data

Dalam menggunakan studi pustaka maka peneliti harus mencari data primer yang berkaitan dengan kasus yang sedang diteliti untuk dijadikan sebagai landasan teoritis dalam penelitian. ${ }^{8}$ Dengan demikian, di dalam penelitian tentang peran Gubernur Jambi untuk mengontrol kebijakan pemerintah daerah dalam menanggulangi covid-19 maka peneliti mengumpulkan terlebih dahulu data primer berupa peraturan perundang-undangan yang berkaitan dengan peran Gubernur Jambi untuk mengontrol kebijakan pemerintah daerah.

\footnotetext{
5 Peter Mahmud Marzuki, Op.Cit, hal 141.

${ }^{6}$ Bambang Sunggono, Metode Penelitian Hukum, (Jakarta : PT RajaGrafindo Persada, 2003), $\quad$ hal 67.

${ }^{7}$ Ibid.

${ }^{8}$ Rianto Adi, Metodologi Penelitian Sosial dan Hukum, (Jakarta : Granit, 2010), hal 57.
} 
6. Definisi Operasional Variabel Penelitian

\section{a. Peran Gubernur Jambi}

Peran adalah sesuatu tugas yang sudah seharusnya dilaksanakan oleh badan hukum, dimana badan hukum terkait hal ini mempunyai kedudukan dan kewenangan di dalam kelompok sosial. Secara umum peran merupakan suatu langkah yang harus dikerjakan oleh orang-orang tertentu baik langkah tersebut dalam bentuk hak maupun kewajiban sesuai dengan amanat yang pernah diamanatkan kepada dirinya sehingga seseorang disebut dapat dikatakan telah menjalankan suatu peranan. ${ }^{9}$

Dengan adanya peran berarti menunjukkan bahwa suatu kehadiran di dalam menentukan terkait dengan proses yang sedang berlangsung. Ada juga yang baik peran sebagai tugas yang diberikan kepada seseorang atau sekelompok orang di dalam masyarakat untuk mewujudkan tujuan tertentu. ${ }^{10}$ Adapun peran yang dimaksud di dalam penelitian ini yaitu peran faktual yang artinya Tugas yang harus dilakukan oleh Gubernur Jambi sebagai lembaga pemerintahan provinsi, dimana tugas tersebut yang didasarkan sesuai dengan peraturan perundangundangan serta dilaksanakan secara nyata di dalam kehidupan masyarakat. Untuk itu, dalam peran ini mencakup paling sedikit tiga hal yaitu : ${ }^{11}$

1) Peranan yang meliputi norma yang dikaitkan dengan seseorang yang mempunyai posisi tertentu di dalam masyarakat. Udah itu, peran diartikan sebagai suatu rangkaian aturan yang mana aturan tersebut menjelaskan terkait dengan pedoman yang harus dilaksanakan kan oleh seseorang terkait dengan hak dan kewajibannya dalam masyarakat.

2) Peran merupakan suatu konsep yang menjelaskan Tentang hal yang seharusnya dilaksanakan oleh seseorang yang di dalam kehidupan bermasyarakat sebagai organisasi.

3) Peran juga dijelaskan sebagai suatu tingkah laku seseorang yang mempunyai kedudukan penting dalam struktur sosial di masyarakat.

Penting dari adanya peran ini adalah hal mengatur terkait dengan perilaku seseorang di dalam kehidupan bermasyarakat sehingga memberikan batasan-batasan kepada seseorang tersebut untuk memprediksi perbuatan lain yang akan menimbulkan kerugian. Selain itu juga, peran dapat memberikan bimbingan kepada seseorang dalam berperilaku aku di masyarakat sebab fungsi dari peran itu sendiri sebagai berikut :

1) Untuk memberikan arahan dalam proses sosialisasi yang dilakukan oleh pemerintah maupun penegak hukum.

2) Dapat menyatukan kelompok yang ada di masyarakat.

3) Membangun sistem pengendalian dan kontrol yang dilakukan oleh pemerintahan yang lebih tinggi sehingga dapat mewujudkan kesejahteraan masyarakat.

Dengan demikian sudah jelas bahwa peran Gubernur dalam hal ini yaitu suatu tugas yang harus dilakukan oleh Gubernur Jambi dalam mengubah struktur sosial maupun melakukan berbagai kebijakan guna untuk melindungi masyarakat Provinsi Jambi.

b. Kebijakan Pemerintah Daerah

Kebijakan merupakan suatu rangkaian dari tindakan yang diusulkan oleh seseorang, kelompok maupun pemerintah dalam suatu permasalahan tertentu di mana dalam hal ini terdapat berbagai macam hambatan dan kesempatan yang dapat dilakukan oleh pengusul kebijakan dalam rangka mencapai suatu tujuan tertentu di masyarakat. ${ }^{12}$ Sebenarnya istilah kebijakan memiliki cakupan yang luas sehingga kebijakan tersebut dapat pula diartikan sebagai suatu usaha yang dilaksanakan oleh pejabat yang memiliki kekuasaan dalam mengurus permasalahan kepentingan umum yang terjadi di dalam masyarakat. ${ }^{13}$

Kebijakan seringkali diartikan sebagai suatu kumpulan dari berbagai keputusan yang dilakukan oleh lembaga yang memiliki kewenangan untuk mengatur, mengendalikan dan melayani masyarakat. Oleh karena itu, suatu kebijakan merupakan keluaran sistem dari yang membuat kebijakan tersebut sehingga dengan adanya kebijakan yang diambil oleh pemerintah diharapkan dapat memecahkan permasalahan yang sedang terjadi di dalam masyarakat. ${ }^{14}$ Selain itu juga, kebijakan adalah suatu pernyataan secara umum, dimana pernyataan

\footnotetext{
${ }^{9}$ Soerjono Soekanto, Teori Peranan, (Jakarta : Bumi Aksara, 2002), hal 243.

${ }^{10}$ Soerjono Soekanto, Sosiologi Suatu Pengantar, (Jakarta : Rajawali Press, 2002), hal 242.

${ }^{11}$ Soerjono Soekanto, Sosiologi Suatu Pengantar, (Jakarta : PT. Rajagrafindo Persada, 2006), $\quad$ hal 213.

${ }^{12}$ Taufiqurakhman, Kebijakan Publik : Pendelegasian Tanggungjawab Negara Kepada Presiden Selaku Penyelenggara Pemerintahan, (Jakarta : Fakultas Ilmu Sosial dan Ilmu Politik Universitas Moestopo Beragama (Pers), 2014$),$ hal 2.

${ }^{13}$ H. M. Hasbullah, Kebijakan Pendidikan (Dalam Perspektif Teori, Aplikasi, dan Kondisi Objektif Pendidikan di Indonesia), (Jakarta : Rajawali Pers, 2015), hal 37.

${ }^{14}$ Mudjia Rahardjo, Pemikiran Kebijakan Pendidikan Kontemporer, (Malang : UIN Maliki Press, 2010$)$, hal 3.
} 
tersebut memberikan pedoman terkait dengan pemikiran untuk mengambil suatu keputusan yang memiliki esensi dalam batasan-batasan tertentu di dalam mengambil sebuah keputusan. ${ }^{15}$

Kemudian pemerintah merupakan suatu alat kelengkapan negara yang memiliki tugas dan fungsi sesuai dengan kedudukannya di dalam pemerintahan sebab pemerintah memegang kekuasaan yang terorganisir. Untuk itu, pemerintah diistilahkan sebagai organisasi di dalam masyarakat yang diberikan hak dan kewajiban oleh negara untuk melaksanakan kekuasaan kedaulatan.

Pengertian pemerintahan daerah menurut Undang-Undang Nomor 23 Tahun 2014 Tentang Pemerintahan Daerah adalah penyelenggaraan urusan pemerintahan oleh pemerintah daerah dan Dewan Perwakilan Rakyat Daerah (DPRD) menggunakan asas otonomi dan tugas pembantuan dengan prinsip otonomi seluas-luasnya dalam sistem dan prinsip Negara Kesatuan Republik Indonesia sebagaimana dimaksud dalam Undang-Undang Dasar Negara Republik Indonesia Tahun 1945.

Penyelenggaraan pemerintah daerah diadakan demi melancarkan pencapaian dalam kesejahteraan masyarakat dengan cara melakukan peningkatan dalam pelayanan kepada masyarakat dan melibatkan masyarakat untuk dapat bersaing dengan daerah lain dengan berpedoman pada demokrasi, keadilan dan kekhasan yang dipunyai oleh masyarakat Indonesia. ${ }^{16}$

Dalam setiap provinsi memiliki pemerintah daerah yang telah ditentukan oleh aturan hukum sehingga setiap pemerintah baik provinsi, kabupaten maupun kota dapat mengatur sendiri urusan pemerintahannya. Pemerintah daerah dapat melaksanakan otonomi secara luas kecuali dalam urusan pemerintah tersebut telah ditentukan aturan hukum sebagai urusan pemerintah pusat. ${ }^{17}$ Oleh karena itu, pemerintah daerah walaupun telah memiliki hak untuk mengeluarkan suatu peraturan daerah dan peraturan lainnya dalam menjalankan otonomi dan tugas pembantuan, akan tetapi pemerintah daerah tidak boleh ikut campur dalam urusan pemerintah pusat. Adapun pemerintah daerah dalam hal ini terdiri dari Gubernur, Bupati, Walikota dan perangkat daerah lainnya.

c. Penanggulangan Covid-19

Apabila dilihat dari akibat yang telah terjadi dari adanya covid-19 ini maka sudah seharusnya dilakukan upaya penanggulangan sehingga tidak meningkat korban yang berjatuhan akibat covid-19 ini. Adapun upaya yang sudah dilaksanakan oleh pemerintah terkait menanggulangi covid-19 ini seperti melakukan tindakan PSBB. Tidak hanya itu saja, di pemerintah daerah juga melakukan tindakan seperti memberlakukan Pemberlakukan Pembatasan Kegiatan Masyarakat (PPKM).

Walaupun telah diberlakukan berbagai kebijakan oleh pemerintah seperti PSBB dan PPKM yang dilakukan oleh pemerintah daerah Jambi, namun di dalam melakukan penanggulangan terkait dengan covid-19 ini harus ada kerjasama antara pemerintah provinsi maupun pemerintah Kabupaten/kota sehingga dalam melakukan penanggulangan covid-19 ini lebih efektif. Selain adanya peran dari Pemerintah Provinsi, Pemerintah Kabupaten maupun Pemerintah Kota, dibutuhkan juga peran serta masyarakat Jambi guna untuk mematuhi berbagai macam kebijakan yang telah dikeluarkan baik oleh Pemerintah Provinsi, Pemerintah Kabupaten maupun Pemerintah Kota Jambi. Dengan ada peran serta masyarakat sebagai pendukung kebijakan pemerintah daerah tersebut sehingga untuk mewujudkan masyarakat Jambi yang bebas dari penyebaran covid19 dapat terwujud.

7. Teknik Analisis

Penelitian tentang peran Gubernur Jambi untuk mengontrol kebijakan pemerintah daerah dalam menanggulangi covid-19 menggunakan teknik analisis kualitatif. Analisis kualitatif ini bertujuan untuk mempermudah Dalam pemahaman terkait dengan kondisi yang sebenarnya terjadi sesuai dengan peristiwa di lapangan. ${ }^{18}$ Untuk itu, penelitian ini menggunakan analisis kualitatif karena dalam penelitian ini akan menjelaskan terkait peran Gubernur Jambi di lapangan dalam mengontrol kebijakan pemerintah daerah yang ada di bawahnya selama masa pandemi covid-19.

\section{HASIL DAN PEMBAHASAN}

Corona virus disease (covid-19) pada saat ini menimbulkan hanyak korban di Provinsi Jambi sehingga diperlukan penanggulangan yang serius agar covid-19 ini dapat berakhir dengan cepat di provinsi Jambi. Di dalam melakukan penanggulangan covid-19 ini sangat diperlukan peran antara pemerintah Provinsi dengan pemerintah Kabupaten/Kota Jambi. Adapun masing-masing peran yang harus dilakukan oleh pemerintah provinsi, kabupaten maupun Kota Jambi sesuai dengan amanat dalam Undang-Undang Nomor 23 Tahun 2014 Tentang Pemerintahan Daerah.

${ }^{15}$ Syaiful Syagala, Administrasi Pendidikan Kontemporer, (Bandung : Alfabeta, 2008), hal 97.

${ }^{16}$ Ani Sri Rahayu, Pengantar Pemerintahan Daerah Kajian Teori, Hukum dan Aplikasinya, (Malang : Sinar Grafika, 2017), hal 1.

${ }^{17}$ Ibid.

${ }^{18}$ Farida Nugrahani, Metode Penelitian Kualitatif dalam Penelitian Pendidikan Bahasa, (Solo : Cakra Books, 2014), hal 4. 
Dalam Undang-Undang Nomor 23 Tahun 2014 Tentang Pemerintahan Daerah ini mengamanatkan kepada setiap pemerintah Provinsi Jambi dalam hal ini Gubernur Jambi untuk menyelenggarakan terkait dengan urusan pemerintahan umum di Provinsi Jambi. Hal yang demikian harus dilakukan oleh Gubernur Jambi karena mengingat perannya sebagai wakil pemerintah pusat untuk menjalankan program pemerintah pusat di provinsinya masingmasing. Sedangkan untuk pemerintah daerah yang berkedudukan di kabupaten maupun kota seperti Bupati dan Walikota Jambi harus menyelenggarakan urusan pemerintahan umum yang telah ditugaskan oleh Gubernur Jambi terkait dengan penanggulangan covid-19.

Mengingat tugas sebagai Pemerintah Daerah yang berkedudukan di kabupaten maupun di kota seperti Walikota Jambi setelah mengeluarkan beberapa kebijakan terkait dengan penanggulangan covid-19 di Provinsi Jambi. Adapun contoh kebijakan yang telah dikeluarkan oleh Walikota Jambi dalam mengatasi permasalahan covid-19 ini seperti Peraturan Walikota Jambi Nomor 21 Tahun 2020 Tentang Pedoman Penanganan Corona Virus Disease (Covid-19) Di Area Publik / Di Lingkungan Usaha Dan Masyarakat Dalam Pemberlakuan Relaksasi Ekonomi Dan Sosial Kemasyarakatan Pada Masa Pandemi dan Instruksi Walikota Jambi Nomor : 18/INS/VIII/HKU/2021 Tentang Pemberlakuan Pembatasan Kegiatan Masyarakat Level 4 Corona Virus Disease Di Wilayah Kota Jambi.

Tidak hanya Walikota Jambi saja yang mengeluarkan terkait dengan kebijakan untuk menanggulangi covid-19 ini, Pemerintah Kabupaten Batanghari juga mengeluarkan kebijakan terkait dengan penanggulangan covid-19 di daerahnya dan kebijakan tersebut yaitu Peraturan Bupati Batanghari Nomor 26 Tahun 2021 Tentang Perubahan Atas Peraturan Bupati Batanghari Nomor 65 Tahun 2020 Tentang Penerapan Disiplin Dan Penegakan Hukum Protokol Kesehatan Sebagai Upaya Pencegahan Dan Pengendalian Corona Virus Disease 2019.

Selain itu juga, Wakil Bupati Merangin juga sudah melakukan rapat internal bersama Organisasi Perangkat Daerah dalam menindaklanjuti terkait dengan adanya Instruksi Menteri Dalam Negeri Nomor 31 Tahun 2021 Tentang Pemberlakuan Pembatasan Kegiatan Masyarakat Level 4 Corona Virus Disease 2019 Di Wilayah Sumatera, Kalimantan, Sulawesi, Nusa Tenggara, Dan Papua. Di dalam rapat ini, Wakil Bupati Merangin akan membahas terkait dengan peningkatan wabah covid-19 variasi baru yang terjadi di Kabupaten Merangin sekarang ini dan memperbarui Surat Edaran tentang perkembangan terkait dengan penyebaran wabah covid-19 di Kabupaten Merangin. ${ }^{19}$

Dengan telah dikeluarkannya kebijakan oleh Walikota Jambi dan Bupati Batanghari dan Wakil Bupati Merangin merupakan suatu kebijakan yang dapat digunakan sesuai dengan ruang lingkup daerah masing-masing dan sesuai dengan isi di dalam Undang-Undang Nomor 23 Tahun 2014 Tentang Pemerintahan Daerah karena dalam undang-undang tersebut memberikan kewenangan terhadap pemerintah daerah masing-masing untuk melakukan otonomi daerah sesuai dengan keadaan dan kebutuhan daerah sendiri.

Walaupun Walikota Jambi dan Bupati Batanghari telah mengeluarkan kebijakan terkait dengan penanggulangan penyebaran covid-19 serta Kabupaten Merangin juga sudah melakukan rapat internal terkait dengan Surat Edaran tentang penanggulangan penyebaran covid-19 di Kabupaten Merangin karena ketiga daerah ini termasuk dalam wilayah level 4 sesuai dengan isi Instruksi Menteri Dalam Negeri Nomor 31 Tahun 2021 Tentang Pemberlakuan Pembatasan Kegiatan Masyarakat Level 4 Corona Virus Disease 2019 Di Wilayah Sumatera, Kalimantan, Sulawesi, Nusa Tenggara, Dan Papua, akan tetapi di dalam menjalankan kebijakan tersebut Walikota Jambi, Bupati Batanghari dan Bupati Merangin harus berkoordinasi juga dengan Gubernur Jambi sebagai wakil pemerintah pusat di daerah guna untuk mengefektifkan semua kebijakan yang telah dikeluarkan oleh pemerintah kabupaten maupun kota dalam melakukan penanggulangan terkait dengan penyebaran covid-19 ini dapat dilakukan secara bersama-sama.

Pada kenyataannya sekarang ini masing-masing pemerintah daerah saling menjalankan perannya masingmasing tanpa berkoordinasi kepada Gubernur sehingga Gubernur Jambi sulit untuk melakukan pengontrolan terkait dengan kebijakan yang telah dibuat oleh Walikota Jambi, Bupati Batanghari dan Bupati Merangin. Seharusnya dalam menjalankan setiap kebijakan baik pemerintah kota maupun kabupaten harus berterima kasih kepada Gubernur selaku pimpinan di provinsi tersebut sehingga apabila terjadi kendala atau kesulitan dalam menerapkan atau menjalankan kebijakan terkait dengan penanggulangan covid-19 ini maka Gubernur selaku pimpinan dapat melakukan tindakan lain kepada Walikota maupun Bupati Batanghari dan Bupati Merangin.

Diadakan pengontrolan oleh pemerintah provinsi kepada pemerintah kabupaten/kota karena untuk memahami dan mengevaluasi hal-hal yang seharusnya dilaksanakan guna untuk menanggulangi covid-19 sesuai dengan wilayah administrasinya masing-masing. Selain itu juga, tidak mungkin pekerjaan yang ada di kabupaten maupun kota dapat dikerjakan oleh Gubernur selaku pimpinan di provinsi maka dari itu dibutuhkan laporan dari Walikota dan Bupati terkait dengan kendala-kendala yang dihadapi oleh Walikota dan Bupati tersebut di dalam melakukan penanggulangan covid-19.

Untuk itu, di dalam menjalankan tugasnya selaku Walikota dan Bupati dalam melakukan otonomi di daerahnya masing-masing maka setelah melakukan otonomi tersebut dalam hal ini melakukan penanggulangan yang berhubungan dengan terkait dengan penularan covid-19 di wilayah Kabupaten Batanghari, Kabupaten Merangin dan

${ }^{19}$ https://editornews.pikiran-rakyat.com/daerah/pr-1312175716/pemerintah-kabupaten-merangin-siapkan-surat-edaranbaru-terkait-ppkm-mikro, Diunduh tanggal 9 Agustus 2021. 
Kota Jambi maka Bupati Batanghari, Bupati Merangin dan Walikota Jambi harus melaporkan terkait dengan hasil yang telah dilakukan mereka dalam menanggulangi covid-19 kepada Gubernur Jambi selaku pimpinan yang berkedudukan di provinsi.

Sebenarnya dilakukan pengumpulan oleh Gubernur Jambi ini guna untuk menyelesaikan berbagai macam permasalahan yang timbul di dalam lintas wilayah administrasi Walikota Jambi, Bupati Batanghari dan Merangin termasuk juga dalam hal ini melakukan penanggulangan terkait dengan penyebaran covid-19 di Jambi. Dengan adanya pengontrolan yang dilakukan oleh Gubernur Jambi maka akan ada beberapa potensi yang dapat ditindaklanjuti baik oleh Gubernur Jambi, Walikota Jambi, Bupati Batanghari dan Bupati Merangin terkait dengan penanggulangan covid19 sehingga dengan mengetahui potensi mana saja yang dapat dilakukan penanggulangan maka Gubernur Jambi, Walikota Jambi, Bupati Batanghari dan Bupati Merangin dapat segera melakukan tindakan di dalam menyelesaikan kasus covid-19 demi melindungi kepentingan bersama dan melindungi masyarakat Jambi dari bahaya penyebaran covid-19.

Mengingat Provinsi Jambi sekarang ini sudah masuk pada level 4 terkait dengan Pemberlakuan Pembatasan Kegiatan Masyarakat (PPKM) maka sudah seharusnya dilakukan pengontrolan oleh Gubernur Jambi terhadap kebijakan yang telah dikeluarkan oleh Walikota Jambi, Bupati Batanghari dan Bupati Merangin. Dengan adanya pengontrolan yang baik oleh Gubernur Jambi terhadap Walikota Jambi, Bupati Batanghari dan Bupati Merangin maka Pemerintah Jambi memiliki kekuatan di masing-masing daerah dalam menanggulangi covid-19 sehingga dapat berjalan dengan sinergis di dalam pemecahan masalah yang terjadi di lapangan jika dibandingkan dengan penanganan covid-19 yang dilakukan sendiri-sendiri oleh Walikota Jambi, Bupati Batanghari dan Bupati Merangin di daerahnya masing-masing.

Kemudian apabila Walikota Jambi, Bupati Batanghari dan Bupati Merangin yang telah melakukan kerjasama dan dikontrol oleh Gubernur Jambi maka akan lebih cepat dalam mencapai kemajuan untuk mengatasi dan menanggulangi penyebaran covid-19 di Jambi. Dengan Kerjasama yang terjalin baik dan dilakukan pengontrolan oleh Gubernur Jambi maka setiap pemerintah daerah tentunya akan terlihat keterampilan dari masing-masing pemerintah daerah tersebut.

Selain itu juga, adanya informasi terkait dengan strategi dalam menanggulangi covid-19 di daerahnya masingmasing dapat juga digunakan untuk membantu pemerintah lain yang sedang mengalami kendala dalam menanggulangi covid-19. Untuk itu, dengan adanya keterampilan dan informasi yang didapatkan dari masing-masing pemerintah daerah Jambi tersebut maka pemerintah Jambi baik Walikota Jambi, Bupati Batanghari dan Bupati Merangin dapat mengembangkan dirinya di dalam menanggulangi penyebaran covid-19 di Jambi dengan melihat keterampilan dan informasi terkait dengan strategi yang dilakukan oleh salah satu pemerintah daerah Jambi.

Pengontrolan yang dilakukan oleh Gubernur Jambi juga akan memperkecil atau mencegah terjadinya konflik antara pemerintah daerah. Dengan adanya pengontrolan yang dilakukan oleh Gubernur Jambi ini, dimana awalnya di setiap pemerintah daerah baik kota maupun kabupaten selalu menunjukkan kemampuannya masing-masing dalam menjalankan tugas sesuai dengan otonomi daerahnya sehingga dikhawatirkan akan terlibat konflik maka pengontrolan ini akan lebih memberikan sikap untuk terjalin kerjasama dan berusaha untuk mengambil pelajaran dari pengalaman pemerintah daerah lain dalam menanggulangi covid-19.

Pengontrolan yang dilakukan oleh Gubernur Jambi akan menimbulkan rasa keadilan terhadap jajaran dibawahnya seperti Walikota Jambi, Bupati Batanghari dan Bupati Merangin. Hal ini dikatakan demikian karena masing-masing pemerintah daerah merasa dirinya tidak dirugikan oleh pemerintah daerah lain sebab adanya transparansi dalam pengontrolan yang dilakukan oleh Gubernur Jambi di dalam melaksanakan hubungan kerjasama. Selain itu juga, pemerintah daerah diberikan akses yang sama Dalam menanggulangi covid-19 sehingga tidak ada yang dirugikan dalam mendapatkan informasi terkait dengan penanggulangan covid-19.

Lebih dari itu, dengan mengontrol yang dilakukan oleh Gubernur Jambi terhadap Walikota Jambi, Bupati Batanghari dan Bupati Merangin akan memelihara keberlanjutan terkait dengan tugasnya masing-masing sebagai pemerintah daerah. Tidak hanya itu saja, dengan pengontrolan yang dilakukan oleh Gubernur Jambi akan menimbulkan komitmen terhadap Walikota Jambi, Bupati Batanghari dan Bupati Merangin untuk tidak melakukan tindakan diluar tugasnya sebagai pemerintah daerah sehingga tidak merugikan salah satu pemerintah daerah yang bertugas dalam menanggulangi covid-19 di Jambi.

Dengan adanya pengontrolan yang dilakukan oleh Gubernur Jambi maka Gubernur Jambi dapat membenahi terkait dengan perannya untuk mengontrol kebijakan pemerintah daerah dalam menanggulangi covid-19 dan Melihat kemampuan yang dimiliki oleh pemerintah daerah dalam menjalankan fungsinya untuk mengatasi dan menanggulangi penyebaran covid-19 di Provinsi Jambi. Selain itu juga, pengontrol yang dilakukan oleh Gubernur Jambi ini maka Gubernur Jambi dapat menentukan atau memilih model-model yang sesuai dengan kebutuhan yang dimiliki oleh Walikota Jambi, Bupati Batanghari dan Bupati Merangin.

Jika dilihat secara normatif maka peran Gubernur Jambi sangat luas dalam menjalankan sistem pemerintahan. Hal yang demikian dapat dilihat di dalam Peraturan Pemerintah Nomor 25 Tahun 2000 Tentang Kewenangan 
Pemerintah Dan Kewenangan Propinsi Sebagai Daerah Otonom, dimana di dalam Peraturan Pemerintah ini menjelaskan bahwa salah satu kewenangan Pemerintah Provinsi sebagai daerah otonomi mencakup kewenangan di bidang pemerintahan dalam lintas Kabupaten/Kota. Oleh karena itu, sudah seharusnya Gubernur Jambi sebagai pemerintah provinsi yang menjalani otonomi daerah harus mengontrol terkait dengan pemerintah di lintas Kabupaten/Kota yaitu mulai dari Walikota sampai dengan Bupati terkait dengan penanggulangan covid-19.

Di dalam menjalani peran Gubernur yang telah diatur dalam Peraturan Pemerintah Nomor 25 Tahun 2000 Tentang Kewenangan Pemerintah Dan Kewenangan Propinsi Sebagai Daerah Otonom maka dalam hal ini Gubernur Jambi tidak hanya sebagai pelaksana kebijakan Pusat, melainkan juga menyediakan bantuan tertentu apabila Walikota Jambi, Bupati Batanghari dan Bupati Merangin membutuhkannya di dalam melakukan penanggulangan covid-19 di daerahnya masing-masing. Untuk itu, diperlukan Pengaturan khusus terkait dengan bantuan seperti fasilitas dan lainnya yang diberikan oleh Gubernur Jambi kepada Walikota Jambi, Bupati Batanghari dan Bupati Merangin yang membutuhkan bantuan tersebut.

Dengan demikian, secara formal sudah jelas bahwa peran Gubernur Jambi harus mengontrol kebijakan pemerintah daerah dalam menanggulangi covid-19 sehingga dapat membantu pemerintah daerah yang mengalami kendala di lapangan dan juga diharuskan kepada pemerintah daerah baik di tingkat kota maupun kabupaten untuk berkoordinasi dan melaporkan hasil temuan di lapangan kepada Gubernur Jambi guna untuk mempercepat penanggulangan covid-19 yang terjadi di provinsi Jambi sekarang ini.

\section{SIMPULAN}

Peran Gubernur Jambi untuk mengontrol kebijakan pemerintah daerah dalam menanggulangi covid-19 adalah sampai sekarang ini peran Gubernur Jambi belum terlaksana dalam mengontrol kebijakan pemerintah daerah di dalam menjalankan pemerintahannya masih sendiri sendiri sehingga kurang bersinergi di dalam menjalankan sistem pemerintahan guna untuk menanggulangi terjadinya penyebaran covid-19.

\section{DAFTAR PUSTAKA \\ Buku}

Adi, Rianto, Metodologi Penelitian Sosial dan Hukum, Jakarta : Granit, 2010

Hasbullah, H. M., Kebijakan Pendidikan (Dalam Perspektif Teori, Aplikasi, dan Kondisi Objektif Pendidikan di Indonesia), Jakarta : Rajawali Pers, 2015

Ibrahim, Johnny, Teori dan Metodologi Penelitian Hukum Normatif, Malang : Bayumedia Publishing, 2012

Nugrahani, Farida, Metode Penelitian Kualitatif dalam Penelitian Pendidikan Bahasa, Solo : Cakra Books, 2014

Marzuki, Peter Mahmud, Penelitian Hukum, Jakarta : Kencana Prenada Media Group, 2011

Rahardjo, Mudjia, Pemikiran Kebijakan Pendidikan Kontemporer, Malang : UIN Maliki Press, 2010

Rahayu, Ani Sri, Pengantar Pemerintahan Daerah Kajian Teori, Hukum dan Aplikasinya, Malang : Sinar Grafika, 2017

Soekanto, Soerjono, Teori Peranan, Jakarta : Bumi Aksara, 2002

Soekanto, Soerjono, Sosiologi Suatu Pengantar, Jakarta : Rajawali Press, 2002

Soekanto, Soerjono, Sosiologi Suatu Pengantar, Jakarta : PT. Rajagrafindo Persada, 2006

Sunggono, Bambang, Metode Penelitian Hukum, Jakarta : PT RajaGrafindo Persada, 2003

Syagala, Syaiful, Administrasi Pendidikan Kontemporer, Bandung : Alfabeta, 2008

Taufiqurakhman, Kebijakan Publik : Pendelegasian Tanggungjawab Negara Kepada Presiden Selaku Penyelenggara Pemerintahan, Jakarta : Fakultas Ilmu Sosial dan Ilmu Politik Universitas Moestopo Beragama (Pers), 2014

\section{Peraturan Perundang-Undangan}

Republik Indonesia, Undang-Undang Nomor 6 Tahun 2018 tentang Karantina Kesehatan

Republik Indonesia, Keputusan Presiden Nomor 11 Tahun 2020 tentang Penetapan Kedaruratan Kesehatan Masyarakat corona virus disease 2019 (covid-19)

Republik Indonesia, Peraturan Pemerintah Nomor 21 Tahun 2020 Tentang Pembatasan Sosial Berskala Besar dalam Rangka Percepatan Penanganan corona virus disease 2019 (Covid-19)

Republik Indonesia, Peraturan Pemerintah Nomor 25 Tahun 2000 Tentang Kewenangan Pemerintah Dan Kewenangan Propinsi Sebagai Daerah Otonom

Republik Indonesia, Instruksi Menteri Dalam Negeri Nomor 25 Tahun 2021 Tentang Pemberlakuan Pembatasan Kegiatan Masyarakat (PPKM) Level 4 Corona Virus Disease 2019 Di Wilayah Sumatera, Kalimantan, Sulawesi, Nusa Tenggara, Maluku Dan Papua. 


\section{Website}

https://editornews.pikiran-rakyat.com/daerah/pr-1312175716/pemerintah-kabupaten-merangin-siapkan-surat-edaranbaru-terkait-ppkm-mikro

https://regional.kontan.co.id/news/berlaku-hingga-23-agustus-ini-daftar-wilayah-ppkm-level-4-di-luar-pulau-jawa-bali 